\title{
Reescravização em Feira de Santana: entre as táticas senhoriais e escravistas
}

(1871-1888)

\author{
Nilmária Oliveira carneiro"; Elciene Rizzato Azevedo ${ }^{2}$; \\ 1. Bolsista PIBIC/CNPq, Graduando em Licenciatura em História, Universidade Estadual de Feira de Santana, e- \\ mail:niu.morena_@hotmail.com \\ 2. Orientador, Departamento de Ciências Humanas e Filosofia), Universidade Estadual de Feira de Santana, e-mail: \\ elciazevedo@gmail.com
}

PALAVRAS-CHAVE: reescravização; estratégias; direito.

\section{INTRODUÇÃO}

Embora atualmente o pesquisador se depare com uma rica historiografia acerca da escravidão, é importante destacar que as discussões sobre essa temática longe de chegarem a uma conclusão definitiva apenas demonstram que ainda há muito a ser estudado. As ações de reescravização é um exemplo disso. Como afirma Keila Grinberg 1 : "pouca atenção, até hoje, foi dada às práticas de reescravização, tanto através da revogação da alforria, quanto da escravidão ilegal de descendentes de indígenas, de libertas ou de africanos chegado ao Brasil após a lei de 1831". Na cidade de Feira de Santana, por exemplo, identifiquei a dissertação de Nascimento ${ }^{2}$. A mesma discute, embora de maneira introdutória, no capítulo III sobre a ocorrência de tais práticas nesta cidade e alega não saber ao certo se a escravização ilegal ou reescravização de gente livre ou liberta acontecia ordinariamente em Feira de Santana e seus arredores, mas assegura que ao menos havia esse risco.

Essa pesquisa pretende partir das questões levantadas por Nascimento para aprofundar a analise dessa documentação atentando não somente para o que a autora caracteriza como "viver sobre si" mais, sobretudo, para os significados e especificidades das ações de reescravização na vida dos negros na cidade de Feira de Santana a fim de identificar as táticas e artifícios usados pelos escravos e senhores nas ações de reescravização, atentando ainda para os conflitos, as resistências, as negociações e lutas desses sujeitos.

\footnotetext{
${ }^{1}$ GRINBERG, Keila. "Senhores sem escravos: a proposito das ações de escravidão no Brasil Imperial”. Almanack Braziliense, n.6, São Paulo, nov. 2007.

${ }^{2}$ NASCIMENTO, Flaviane Ribeiro. "Viver por si: historias de liberdade no agreste baiano oitocentista (Feira de Santana, 1850-1888)”, Salvador, BA: UFBA, 2012.
} 
Levando em conta ainda Keila Grinberg ${ }^{3}$ que considera o Direito como um campo de disputas entre os grupos sociais diversos com projetos divergentes, dessa forma é possível compreender a razão pela qual os escravos, ao se sentirem ameaçados recorriam à justiça, muitas vezes impulsionados pelo fato de não conseguirem resolver no âmbito privado o que era levado ao âmbito público, como salienta a autora. Sendo assim, o que se pode concluir é que os escravos tinham consciência que recorrer ao tribunal campo do Direito era uma possibilidade de luta, na qual o resultado poderia beneficia-los.

$\mathrm{Na}$ mesma perspectiva teórica trabalha Mariana Armond Dias Paes ${ }^{4}$, a qual discute as ações de manutenção de liberdade a partir de um olhar que se volta sobre o campo da História do Direito e leva em conta duas questões fundamentais: como as ações de manutenção de liberdade eram reconhecidas como procedimento judicial e a que fatores se devem a regularização desse procedimento em 1840 e seu aumento em 1860. Segundo a autora o "viver sobre si" tinha um significado específico que vai além de um significado social sendo traduzido no campo jurídico a partir de uma noção de posse da liberdade

\section{MATERIAL E MÉTODOS OU METODOLOGIA (ou equivalente)}

Foram selecionados seis processos cíveis, os quais se constituem como ações de manutenção de liberdade, datando entre os anos de 1876 a 1884. A metodologia consiste basicamente durante todo o trabalho na análise desses, bem como seu cruzamento com as referências bibliográficas e verbetes do Jornal Vida Feirense, de 1858, o qual apesar de não se enquadrar dentro do recorte temporal desse trabalho contribui para que se reflita sobre o contexto de Feira de Santana no século XIX, fato esse de suma relevância na análise das fontes.

\section{Fontes levantadas do arquivo Público do Estado da Bahia (APEB)}

Do arquivo Público do Estado da Bahia (APEB)

Processos cíveis:

1884- APEB, Processo cível, sessão judiciária 68/ 2422/ 05;

\footnotetext{
3 GRINBERG, Keila. "Reescravização, direitos e justiças no Brasil no século XIX”, in LARA Silvia Hunold e MENDONÇA, Joseli M. Nunes (Orgs.). Direitos e Justiça no Brasil: ensaios de história social. Campinas: Ed. UNICAMP, 2006.

4 MARIANA, Armond Dias Paes. O procedimento de manutenção de liberdade no Brasil oitocentista. Rio de janeiro. Vol. 29, Nº58. 2016.
} 
1877- APEB, Processo cível, sessão judiciária 82/ 2941/ 03;

1876- APEB, Processo cível, sessão judiciária 56/ 1997/05; 1877 -

APEB, processo cível, sessão judiciária 82/ 2941/04.

\section{Fontes Impressas:}

Museu Casa do Sertão: Verbetes do Jornal Vida Feirense 1858 (Museu Casa do Sertão).

\section{RESULTADOS E/OU DISCUSSÃO (ou Análise e discussão dos resultados)}

$\mathrm{Na}$ medida em que foi feita a leitura das fontes e aprofundamento do conhecimento sobre o tema, tanto por meio da leitura dos textos base como de tantos outros que tinham relação com a temática, percebeu-se que o campo do direito e as leis citadas nas fontes interferiam, às vezes de maneira definitiva, no resultado final de uma ação de liberdade. Dessa forma, pode-se afirmar que o uso social da lei, a interpretação que o advogado dá a essas leis em contextos diversos são parte das estratégias e táticas para alcançar a liberdade. As ações encontradas durante essa pesquisa demonstram quão instável deveria ser a situação dos libertos que, às vezes, apesar de reconhecidamente viverem como livres por muitos anos, ainda precisavam voltar a justiça para consolidar seus direitos.

\section{CONSIDERAÇÕES FINAIS (ou Conclusão)}

O desenvolvimento desse trabalho e a pesquisa realizada no APEB apontam para o fato de que a reescravização, assim como em outras partes do Império, foi uma ameaça aos homens e mulheres negros e pobres que viveram em Feira de Santana na segunda metade do século XIX. Talvez não com tanta frequência, mas o documento apresentado acima e, sobretudo, a leitura das referencias bibliográficas dão suporte para que se faça tal afirmação.

\section{REFERÊNCIAS}

AZEVEDO, Elciene. “O Direito dos Escravos: Lutas jurídicas e abolicionismo na província de São Paulo”. Campinas, Ed. da Unicamp, 2010.

CHALHOUB, Sidney. "A força da escravidão: ilegalidade e costume no Brasil oitocentista” São Paulo: Companhia das Letras, 2012.

FERREIRA, Elisangela Oliveira. Os laços de uma família: da escravidão à liberdade nos sertões do São Francisco. 2005 
GRINBERG, Keila. “Senhores sem escravos: a proposito das ações de escravidão no Brasil Imperial”. Almanack Braziliense, n.6, São Paulo, nov. 2007.

GRINBERG, Keila. "Reescravizacao, direitos e justicas no Brasil no seculo XIX", in LARA Silvia Hunold e MENDONCA, Joseli M. Nunes (Orgs.). Direitos e Justiça no Brasil: ensaios de historia social. Campinas: Ed. UNICAMP, 2006.

MARIANA, Armond Dias Paes. O procedimento de manutenção de liberdade no Brasil oitocentista. Rio de janeiro. Vol. 29, N58. 2016.

NASCIMENTO, Flaviane Ribeiro. "Viver por si: historias de liberdade no agreste baiano oitocentista (Feira de Santana, 1850-1888)”, Salvador, BA: UFBA, 2012. 